\title{
Ethnic outbidding and nested competition: Explaining the extremism of ethnonational minority parties in Europe
}

\author{
CHRISTINA ISABEL ZUBER ${ }^{1} \&$ EDINA SZÖCSIK ${ }^{2}$ \\ ${ }^{1}$ University of Konstanz, Germany; ${ }^{2}$ University of Bern, Switzerland
}

\begin{abstract}
The classical outbidding model of ethnic politics argues that democratic competition involving ethnic parties inevitably leads to ethnic outbidding where parties adopt ever more extreme positions. However, recent small-N studies show that ethnic outbidding is only one of a range of strategies available to ethnic parties. This article seeks to explain why some ethnic parties are extremist, whereas others adopt moderate positions. Drawing on the ethnic outbidding and the nested competition model of ethnic party competition, it is hypothesised that the ethnic segmentation of the electoral market, and the relative salience of an ethnically cross-cutting economic dimension of party competition, account for the varying degrees of extremism. Hypotheses are tested drawing on a novel, expert-survey-based dataset that provides indicators for the positions of 83 ethnonational minority parties in 22 European democracies in 2011. Results of ordinary least squares and two-level linear regressions show that as the economic dimension gains importance, parties become more moderate relative to the party system mean. The electorate's ethnic segmentation has a positive effect on extremism, but this effect is not significant in all models. Contrary to expectations, higher ethnic segmentation of the party system is associated with more moderate positions in the majority of the estimated models.
\end{abstract}

Keywords: ethnonational minority parties; party competition; ethnic segmentation; salience; multinational democracies

\section{Introduction}

Arguing that democracy cannot be stable in ethnically heterogeneous societies has a long tradition. It dates back to John Stuart Mill's often-cited statement that 'free institutions are next to impossible in a country made up of different nationalities' (Mill 1861:296). Rabushka and Shepsle's $(1971,1972)$ model of ethnic outbidding provides a causal mechanism that can account for this pessimistic assessment (Chandra 2005: 235). The ethnic outbidding model argues that parties in ethnically heterogeneous societies appeal to voters on the basis of their ethnic identity ${ }^{1}$ rather than other social identities, such as class. Assuming that ethnic groups have mutually exclusive political preferences, parties seek to maximise votes by adopting more extreme positions than their intra-ethnic competitors (for a similar description, see Horowitz 1985: Part 3). However, this expectation of extremist outbidding has recently been challenged by empirical findings from two largely unconnected literatures: those on ethnic politics and on territorial politics.

Recent small-N studies in the field of ethnic politics show that 'extremist outbidding in ethnic party systems is not inevitable' (Mitchell et al. 2009). These studies present ethnic parties as flexible actors where outbidding constitutes only one among a range of mobilisation strategies. Chandra (2005) shows that ethnic parties may begin to appeal to an alternative ethnic identity category, rather than outbid their opponents, if ethnic 
identity categories are fluid and multidimensional and democratic institutions allow parties to change identity categories. Coakley (2008: 769-770) mentions that, apart from ethnic outbidding, parties may pursue the strategy of ethnic underbidding, emphasising the moderate middle ground between the groups, or pick the strategy of non-ethnic counterbidding, emphasising a cleavage that cross-cuts the ethnic divide. Zuber's (2013) case studies of minority parties in Serbia suggest that strategies other than outbidding are chosen if ethnic parties have office goals and see themselves as competing with both ethnic and non-ethnic parties. ${ }^{2}$ Szöcsik and Bochsler (2013) explain the variance in the policy positions of several parties that appeal to the same ethnonational minority group by arguing that government inclusion affects the dynamics of intra-ethnic competition that might result in moderation. Mitchell et al. (2009) find that the nationalist parties' vote shares in Northern Ireland in fact increased when they moderated their stances under the influence of the power-sharing arrangement.

The ethnic politics literature accounts for the behaviour of ethnic parties worldwide. By contrast, the literature on territorial party politics focuses on political parties in Western democracies. An empirical overlap between both literatures exists where scholars of territorial politics study a special type of ethnic party - namely 'ethno-regionalist parties', defined as parties whose 'primary raison d'être is the improvement of the cultural, social, economic, and political conditions of its potential ethnic constituency by decentralizing or dissolving the state to provide the region with a governmental structure designed to serve the ethnoregion's needs efficiently' (Newman 1997: 58, fn 1). ${ }^{3}$ Even though authors in this field do not explicitly engage with theories of ethnic party competition, they have provided further empirical evidence against the prediction of the outbidding model, showing (1) that not all ethno-regionalist parties are secessionists, but that they choose flexibly between the programmatic options of regional autonomy within, and secession from the state (Newman 1997; Massetti 2009; Massetti \& Schakel 2013a; Tronconi 2006), and (2) that extreme, secessionist positions can have a negative effect on parties' vote share (Montabes Pereira et al. 2006).

In light of these findings, this article seeks to explain why some ethnic parties are extremist whereas others adopt moderate positions. We draw on two theoretical accounts of ethnic party competition to develop hypotheses: the ethnic outbidding model and the nested competition model. Arguments of ethnic outbidding explain extremism with intraethnic competition in a perfectly ethnically segmented electoral market (Horowitz 1985: Part 3; Rabushka \& Shepsle 1971, 1972). Arguments of nested competition account for the fact that ethnic parties also exist in imperfectly segmented markets where they compete with non-ethnic parties on ethnically cross-cutting dimensions of competition, which sets incentives for moderation (Zuber 2012). On the basis of these models, we hypothesise that the ethnic segmentation of the electoral market, and the relative salience of an ethnically cross-cutting economic dimension of competition, account for varying degrees of extremism in the positions of ethnonational minority parties.

We test these hypotheses through a cross-sectional analysis of varying extremism in the positions that European ethnonational minority parties adopt on the ethnonational dimension of party competition in 2011. We define 'ethnonational minority parties' as a subcategory of 'ethnic parties'. An ethnonational minority party is an ethnic party that seeks to represent an ethnic minority group that conceives itself as a nation (or as belonging 
to a kin nation $)^{4}$ on the basis of a historical homeland territory. As we explain in more detail below, focusing on European ethnonational minority parties for testing theories of ethnic party competition has a few advantages: the concept of an ethnonational minority party ensures comparability across cases; unlike ethno-regionalist parties, ethnonational minority parties are not defined through a particular programmatic position; and focusing on European parties optimises the trade-off between validity and variance.

Existing datasets in the field of ethnic politics have so far neglected the heterogeneous platforms of ethnic parties: 'We lack the cross-national data on the positions taken by ethnic parties that would allow a systematic empirical test of the outbidding models' (Chandra, 2005: 238). In the field of territorial party politics, considerable progress has recently been made in measuring and analysing the territorial demands of regionalist parties in Western democracies (Massetti 2009; Massetti \& Schakel 2013a, 2013b). However, a data source systematically covering the positions of ethnonational minority parties across Europe has so far been lacking. This article draws on EPAC, a novel dataset on ethnonationalism in party competition that provides the positions of 83 ethnonational minority parties in 22 European democracies. The data were collected by the authors, who surveyed experts between June and November 2011 (Szöcsik \& Zuber 2015).

Results of ordinary least squares (OLS) and two-level linear regression models confirm that as the economic dimension of competition gains importance relative to the ethnonational dimension, parties become more moderate relative to the party system mean. The electorate's ethnic segmentation has a positive effect on extremism, but this effect is not significant in all models. Contrary to our expectations, the results of the majority of the estimated models show that higher ethnic segmentation of the party system is associated with more moderate ethnonationalist minority parties. Since our measure of supply-side segmentation is based on the seat shares of ethnic majority and minority parties in national and regional parliaments, this finding could indicate a moderating effect of representation and policy influence of ethnonationalist minority parties' inclusion in the legislative arena. In addition, disproportional and minority friendly electoral rules have a moderating effect, whereas asymmetrical territorial autonomy is positively associated with extremism.

The rest of the article is structured as follows. It begins with a discussion of the theoretical models of ethnic party competition and the deriving of hypotheses on ethnic party extremism. Thereafter is an explanation of how we selected the parties; an introduction to the measurement of the variables and the method of analysis; and a discussion of the results of the OLS regression analyses and robustness checks. The final section provides our conclusions.

\section{Theory and hypotheses}

According to Rabushka and Shepsle (1971, 1972; see also Horowitz 1985: Part 3), an inevitable mechanism of ethnic outbidding unfolds in plural societies as parties begin to appeal to voters on the basis of their ethnic identification. The model assumes that in societies where ethnic identity is politically mobilised, ethnic groups have intransigent, mutually exclusive political preferences. In these circumstances, parties cannot gain votes by making offers directed at a moderate middle ground but must adopt more extreme positions 
than their competitors. As a consequence, the electoral market is segmented not only with regard to the demand side of voting behaviour, but also with regard to the supply side of parties' programmatic appeals. As it is only rewarding for parties to appeal exclusively to voters of 'their' ethnic group and voters are assumed to be radical, parties ultimately converge towards the radical end of each spectrum of group-specific interests (Rabushka $\&$ Shepsle 1971: 470). Therefore, in the scenario of ethnic outbidding, party competition occurs only within intra-ethnic arenas and in a one-dimensional policy space: 'Politics in the plural society, by assumption, is restricted to the single dimension of ethnicity' (Rabushka \& Shepsle 1972: 66). Developments in intra-ethnic competition between Hungarian minority parties in Romania exemplify this model. Electoral competition in Romania is largely ethnically segmented. During the first decade after Romania's democratic transition, the Democratic Alliance of Hungarians in Romania (UDMR) was the only party representing the Hungarian minority. In 1996, the party joined the government, which required it to moderate by dropping the goal of territorial autonomy for the Hungarian enclave in the Romanian region of Transylvania. Since 2000, new Hungarian-minority parties, such as the Hungarian Civic Party (PCM) in 2008 and the Hungarian People's Party of Transylvania (PPMT) in 2011, have emerged. They are outbidding the UDMR by demanding territorial autonomy for the Hungarian enclave.

A recent theoretical approach challenges the segmentation assumption of the outbidding model and argues that given imperfectly ethnically segmented voting behaviour and party systems, electoral competition may provide incentives for the moderation of ethnic parties (Zuber 2012). In imperfectly segmented markets, not all voters vote along ethnic lines and ethnic parties exist alongside non-ethnic parties that appeal to voters irrespective of their ethnicity. Intra-ethnic arenas of competition are therefore nested within a non-ethnic arena of competition and this situation is labelled 'nested competition' with reference to Tsebelis' (1990) theory of nested games. As a consequence, some ethnic parties may choose to compete with non-ethnic parties, while others remain exclusively focused on their intraethnic competitors. Therefore, predictions about the positions of parties involved in intraethnic competition need to be differentiated from predictions about the positions of ethnic parties involved in nested competition (Zuber 2012: 928).

Importantly, ethnic parties competing with non-ethnic parties may find it worthwhile to combine their stances on the ethnonational dimension with policy positions on an ethnically cross-cutting dimension of competition. These parties can then be expected to adopt less extreme positions than might seem rational from the perspective of competition in the intraethnic arena because appealing to ethnically cross-cutting voters on an additional dimension of competition would be hard to reconcile with a radical stance on the ethnic dimension (Alonso 2005: 17-18; Zuber 2012: 934). That minority party elites tend to be well aware of how segmented the market is, and who their main competitors are, is exemplified by the following statement from a member of the Serbian parliament representing the Alliance of Vojvodina Hungarians (a Hungarian minority party):

One third of Hungarians in Vojvodina [a region in northern Serbia bordering Hungary] does not vote. One third votes for us, but one third votes for the Democratic Party [a non-ethnic party]. (Author interview with Elvira Kovacs, Belgrade, 12 May 2010) 
The Democratic Party was able to attract these votes from the Hungarian minority because it combined a non-nationalist, minority-friendly stance with a position supporting European integration and social and economic policies that were of great importance to Hungarian voters. Acknowledging that they were no longer competing primarily with other Hungarian parties, but with a non-ethnic party, the Alliance of Vojvodina Hungarians adopted a position on regional economic development while moderating their stance on the ethnonational dimension from territorial to cultural autonomy (Zuber 2012).

In sum, the outbidding model relies on perfectly ethnically segmented electoral competition where ethnic parties compete exclusively with parties seeking to appeal to the same group and where the ethnic dimension is the only salient dimension for all parties and voters. In this model, parties are expected to adopt more extreme positions on the ethnic dimension than their competitors. However, segmentation and salience are variable parameters that open up the possibility of an alternative scenario, which is captured by the model of nested competition: an imperfectly ethnically segmented electoral market where parties compete on ethnic and non-ethnic dimensions and consider these dimensions to be of varying importance. Parties competing simultaneously on the ethnic dimension, and one or more additional dimensions of competition, are then expected to moderate their stances on ethnic issues.

Both theories thus explain the strategic choices of parties in the function of segmentation and salience, taken to be exogenous. However, they acknowledge that the relationship between segmentation and party strategies is endogenous from a dynamic perspective. Parties actively try to influence whether voters define their interests in ethnic or non-ethnic terms. Whereas the segmentation of the electoral market at $t_{-1}$ is therefore parametric to the strategic choices of parties at $t_{0}$, the segmentation of the electoral market at $t_{1}$ is endogenous to the competitive behaviour of ethnic and non-ethnic parties at $t_{0} .^{5}$ Rabushka and Shepsle (1972: 65) state that a theory of ethnic entrepreneurship would be needed to explain when and why the ethnic dimension becomes salient, acknowledging that parties (as entrepreneurs) can affect the salience of ethnic and other issues and shape the dimensionality of the space. However, they do not themselves contribute such a theory. Instead, they present a spatial model where voter preferences on a salient ethnic dimension are assumed to be exogenous. Similarly, Zuber $(2012$ : 932, 941) acknowledges that in the long run, parties can themselves aim to segment or de-segment the electoral market, but argues that parties' strategic choices at a given point in time can be modelled as a function of the given level of segmentation. Minority parties observe that voters defect to nonethnic parties thus receiving a signal that the market is no longer fully segmented. They respond by competing on alternative dimension and moderate their position on the ethnic dimension. While acknowledging that the causal relationship between segmentation and extremism is endogenous, both models thus argue that when deciding on programmatic positions, parties see themselves confronted with a given level of segmentation that can be taken as exogenous for that moment, even though it is endogenous in the long run. The models thus have empirical implications that can be tested with cross-sectional data.

A first testable implication of both models is that more extreme positions among parties operating within more ethnically segmented electoral markets should be expected. We differentiate between demand- and supply-side segmentation, where the former describes 
the extent to which identity predicts voter choice and the latter indicates the share of ethnic parties within the party system. This leads to the following hypotheses:

H1a: The higher the level of demand-side segmentation, the more extreme the positions of ethnonational minority parties on the ethnonational dimension.

$H 1 b$ : The higher the level of supply-side segmentation, the more extreme the positions of ethnonational minority parties on the ethnonational dimension.

An additional testable implication of the nested competition model is that parties, for which the ethnonational dimension is more salient than alternative dimensions, will adopt more extreme stances on this dimension than parties that consider this dimension to be less important. By contrast, parties that consider other dimensions to be more important than the ethnonational dimension are expected to adopt more moderate positions on ethnonational issues. In contemporary European democracies, the most prominent dimension of competition is the economic one (Wagner 2012: 850-851). Defining the economic dimension as the main alternative dimension in political competition, therefore, ensures comparability across cases and countries. On this dimension, state-interventionist parties confront parties in favour of free markets and a lean state (Marks et al. 2006). This leads to the following hypothesis:

H2: The more relative importance a party attaches to the economic dimension of competition, the less extreme is its position on the ethnonational dimension.

\section{Identifying ethnonational minority parties in Europe}

We define 'ethnonational parties' as a sub-category of the class of ethnic parties. An ethnonational party seeks to represent an ethnic group that conceives itself as a nation (or as belonging to a kin nation) on the basis of a historical homeland territory. Like Chandra's (2005: 236) more general definition of an 'ethnic party' - and in contrast to the definition provided by Horowitz (1985:293) - our definition is based on the party's appeal, rather than the distribution of its electoral support (Chandra 2011). An appeal-based definition allows for the singling out of those parties that deliberately seek to attract voters on the basis of their ethnic identity and can therefore be expected to choose a position on the ethnonational dimension.

Focusing on European ethnonational minority parties for testing theories of ethnic competition has several advantages. First, the concept of an 'ethnonational minority party' ensures comparability across cases. Ethnic parties that cannot appeal to territorial identity categories because the group they seek to represent is territorially dispersed and that cannot draw on imagined national communities (Anderson 1991:6) at the sub-state level have a smaller range of positions available to them than parties that appeal to territorially based groups. Only ethnonational minority parties can present their states with the maximum challenge to territorial integrity: secessionist peripheral nation-building (Alonso 2012: 1), or irredentist projects. In addition, whereas dynamics of ethnic party competition are expected to evolve in both ethnic majority and ethnic minority groups, extremist positions of ethnic majority parties (i.e., assimilation) are empirically different from and not easily comparable to the extremist positions of minority parties (i.e., independence). Therefore, 
neither minority parties without a home territory nor majority parties can be analysed in the same sample with ethnonational minority parties.

Second, the concept of an ethnonational minority party does not imply a particular programmatic position. By contrast, the concept of an ethno-regionalist party that is used in the territorial politics literature is defined in programmatic terms - namely through demands for territorial self-government (Newman 1997: 58). The spectrum of possible demands parties can make ranges then only from territorial autonomy within the state to secession from the state. However, some ethnonational minority parties in Eastern Europe make more moderate demands. They aim for decentralisation and local self-government, but do not demand territorial autonomy for their historical homeland.

Third, focusing on European cases optimises the trade-off between validity and variance. The meaning of ethnonational identity is more similar between European democracies that share history of the origins and rise of nationalist ideology than between the European and postcolonial democracies of Africa, Asia and Latin America. At the same time, ethnonational minority parties in Europe display a high degree of variance in the extremism of their positions, with some parties adopting moderate, non-nationalist positions in favour of maintaining a common state, while others opt in favour of secession.

To compile a set of ethnonational minority parties, we first selected all European democracies where at least one ethnic group is considered to be politically relevant within the country assessments provided by the Ethnic Power Relations dataset project (EPRETH) (Cederman et al. 2009, 2010). We consider a country to be democratic if it is rated 'free' or 'partly free' on the Freedom House index and classified as a 'democracy' by the Polity IV project. The EPR-ETH project categorises 'an ethnic group as politically relevant if at least one political organization claims to represent it in national politics or if its members are subjected to state-led political discrimination' (Cederman et al. 2010: 99). These criteria led to a selection of 22 democracies. ${ }^{6}$ We then listed all politically relevant ethnic groups (hereafter 'EPR groups') within these countries in 2009, using the most recent update of the EPR-ETH dataset. From the listed EPR groups, we excluded: (a) the Roma, because their identity is not linked to territory; and (b) migrant groups. We then searched for parties potentially appealing to the remaining EPR groups by checking the secondary literature, party websites, information about parties on Wikipedia and party names. The expert survey was then carried out on the parties with potential EPR group appeal if they had gained at least one seat in their national parliament in the most recent parliamentary elections, or at least one seat and at least 3 per cent of the subnational votes in at least one region in the last regional elections (as of June 2011). We obtained party position estimates for this initial list of parties from between four and ten experts per country. We then singled out two sets of parties following our appeal-based definition of an 'ethnonational minority party': a set explicitly appealing to an EPR minority group in its official party documents; and a set deemed to be seeking to represent an EPR minority group by EPAC country experts, whereby the experts were expected to have information about both explicit and implicit ethnic appeal (for a discussion of explicit and implicit appeal, see Chandra 2011: 160-2).

Selecting parties on the basis of their explicit appeal in official party documents constitutes the most conservative method of selecting ethnonational minority parties in Europe. Following Chandra's (2011: 160) suggestions, we first searched a party's statutes and its electoral manifestos to ascertain whether EPR groups are mentioned. We then 
established whether this appeal to an EPR group is central to the party's platform by searching for 'all-encompassing statement[s] in favour of the interests of an ethnic category or categories' (Chandra 2011: 160). For example, we included ProDG, a party that seeks to represent the Germans in Belgium (listed by EPR-ETH as a politically relevant ethnic group), on the basis of the following statement in its basic programme: 'We understand ourselves as a political force in East-Belgium ... that champions the interests of Germanspeaking Belgians' (ProDG n.d.: 8, authors' translation). ${ }^{7}$ We then excluded multi-ethnic parties that appeal to all relevant ethnic categories. ${ }^{8}$ The final document-based selection consists of 60 parties explicitly seeking to represent the interests of 41 EPR groups in 22 European democracies.

However, there might be strategic incentives for extreme parties to formulate a more inclusive appeal to all citizens within their official documents, while sending coded signals to a more narrow set of ethnic voters. Selecting ethnonational parties on the basis of official documents could bias an analysis of their extremism. Implicit appeals can only be recognised on the basis of in-depth contextual knowledge. We therefore selected an alternative set of parties by using the following question in the expert survey: 'Does the party seek to represent an ethnonational group in politics?' Parties were coded as ethnonational if a twothirds majority of the country experts (excluding those that ticked 'no answer') answered the question in the affirmative. Experts responding in the affirmative were prompted to identify the names of the represented groups in an open-answer question. This enabled us to match parties to EPR minority groups. The final expert selection consists of 75 parties seeking to represent 39 EPR groups in 20 democracies (for a list of parties, see Appendix E).

\section{Operationalisation and method}

To measure extremism, we use a question from the EPAC expert survey that enables the ranking of majority and minority ethnonational parties according to how much congruence they seek between the boundaries of the ethnonational group and the boundaries of the political unit. The most extreme position a minority party can occupy is a position in favour of separating the minority region from the multinational state through secession, constituting a new nation-state where the former minority would gain the status of the titular nation, or uniting the minority territory with its kin state. The survey question follows Gellner's (1994: 35) seminal definition of nationalism as an ideology that propagates the concept that the boundaries of the ethnic group and the political unit should coincide:

In multinational states, parties may have different positions on the status of ethnonational groups and the nature of the state. At one end of the spectrum (0), majority nationalists seek hegemony within the current state they define as their nation-state. At the other end of the spectrum (10), minority nationalists seek to become the hegemonic majority in a new nation-state. Moderate parties of the middle ground (5) seek a common state, in which no single ethno-national group dominates over another. Please indicate the position of each party with only one ' $x$ ' per row.

Both theories of ethnic party competition conceptualise parties' extremism in relative terms - that is, parties are more moderate or more extreme than their competitors. We therefore construct a dependent variable that measures ethnonational minority parties' extremism 
in comparison with each party system mean. ${ }^{9}$ First, we calculate the mean position on ethnonational issues within the party system based on the positions of all parties covered by the EPAC survey ${ }^{10}$ and that participated in the most recent national elections, as at June 2011 (weighing the positions with the parties' seat shares in the national parliament). Second, we subtract the ethnonational position of each minority party from the party system mean.

Previous validity tests showed that experts provided unbiased estimates for the majority of parties - that is, they provided estimates of party positions that were unaffected by their own political preferences. The overall inter-expert correlation when locating parties on the ethnonationalism scale was 0.941 , indicating that the estimates of party positions on the scale used to construct the dependent variable are highly reliable (Szöcsik \& Zuber 2015). A partial external validity test of the data was conducted by Alonso et al. (2013:206-208), who cross-validated their manifesto-based data on Spanish party positions on a centre-periphery dimension with EPAC data for Spain. Their results point to high correspondence in terms of party positions, but show that experts tend to overestimate the salience of the ethnonational dimension. Because the overestimation of salience is not driven by individual parties but affects expert judgments of all parties alike, and since we use relative saliency scores in our analysis (see below), the finding that salience is overestimated in absolute terms when comparing the EPAC data to manifesto-based saliency scores should not bias our analyses.

To measure demand-side segmentation (i.e., the degree to which voters vote along ethnic lines), we employ the survey-based measure of ethnic voting by country suggested by Huber (2012). The Party Vote Fractionalization (PVF) measure is inspired by ethnic fractionalisation indices that calculate the likelihood that two individuals do not belong to the same ethnic group. Following Huber (2012:991), we calculate demand-side segmentation on the basis of a formula that compares pairs of parties with regard to their ethnic constituencies and aggregates this information at the level of the party system:

$$
P V F=\sum_{i=1}^{P} \sum_{j=1}^{P} p_{i} p_{j} \tilde{r_{i j}}
$$

In this formula, $p$ denotes the total number of parties and $\mathrm{p}_{\mathrm{i}}$ and $\mathrm{p}_{\mathrm{j}}$ denote the proportion of voters who support party $i$ and party $j$. Finally, $r_{i j}$ is the distance between the ethnic profiles of two parties $i$ and $j$ and it increases in line with the ethnic support bases of the two parties.

We accounted for the fact that if territorial autonomy solutions are institutionalised, ethnonational minority parties can realise their goals within 'their' region and can therefore be expected to take the electorate and the competitors within the autonomous minority region as their main point of reference (Deschouwer 2003; Elias \& Tronconi 2011). We thus use regional survey data to calculate supply-side segmentation in those cases where the group that a party appeals to enjoys asymmetrical territorial autonomy. Wherever possible, we lagged demand-side segmentation using surveys conducted before June 2011, the point in time when we measure parties' extremism to avoid problems of endogeneity affecting the relationship between segmentation and extremism. Appendix B provides a more detailed discussion of our proceedings and an overview of the surveys.

The variable supply-side segmentation is measured as the relative seat share of both ethnonational majority and ethnonational minority parties in the state-wide (or regional) ${ }^{11}$ parliament following the most recent parliamentary (or regional assembly) election, as at 
June 2011. The reasoning behind this measure is that the greater the aggregate seat share of ethnic parties, the more ethnically segmented the party system. ${ }^{12}$

To measure the relative importance of economic issues for a party, we rely on the EPAC data that records mean values of experts' answers to the questions 'How important are economic issues for each party?' and 'How important are ethnonational issues for each party?', with the scale ranging from 0 (not important at all) to 10 (extremely important). We subtract the importance of ethnonational from the importance of economic issues for each party.

Institutional factors likely to affect the relationship between the explanatory variables and party extremism need to be controlled. Asymmetrical federalism and electoral rules are likely to affect both our independent and our dependent variables. The direction of the effect of territorial autonomy has been disputed. On the one hand, scholars argue that territorial autonomy raises the pay-off of remaining within the multinational state for minority elites in their region. On the other hand, territorial autonomy may itself provide the resources for minority elites to radicalise and seek independence in the longer run (Kymlicka 1998). Scholars studying multinational democracies have further clarified that what matters is not the establishment of a regional tier of government per se, but asymmetrical territorial autonomy - that is, special rights of the minority region (Stepan 2001: 327-328). Only a de jure asymmetrical solution that grants more rights to territorial units inhabited by national minorities than to units inhabited by members of the majority nation can hope to accommodate the self-determination demands voiced by minorities (Agranoff 1999: 97).

We follow these arguments about the importance of relative (i.e., asymmetrical) autonomy. The relationship between asymmetrical territorial autonomy and ethnic party extremism is likely to be endogenous since ethnic parties that make more radical claims may be accommodated with asymmetrical rights in the first place. The dummy variable asymmetrical autonomy takes the value 1 if a de jure asymmetrical territorial autonomy arrangement that benefits the minority a party appeals to is in place. The variable was coded on the basis of McGarry (2005:304) and Benedikter (2009: 65), which we updated. ${ }^{13}$

Furthermore, the electoral system not only affects the logic of party competition, but may also affect our dependent variable. On the one hand, proportional representation has been suggested as a tool for managing conflict (Cohen 1997) as it may mitigate the extremism of ethnic elites by providing more possibilities to participate in parliament and to articulate minority interests therein. On the other hand, proportional representation and eased conditions for minority parties might lead to the proliferation of intra-ethnic competitors (Bochsler 2012), which raises the chances of ethnic outbidding. We account for effects of the electoral system with two variables - disproportionality and minorityfriendly electoral rules - with the former being measured through the least squares index of disproportionality (Gallagher 1991; Gallagher \& Mitchell 2008).

The variable minority-friendly electoral rules is a dummy variable that takes the value 1 if Reynolds (2006: 16-18) mentions any mechanism for special minority protection through the electoral system and coded 0 if no special minority mechanism is mentioned. We updated Reynolds' information on the basis of Bieber (2008: 104-105) and our own research.

To analyse the effects of segmentation, salience and institutional controls on extremism we estimate OLS regression models and linear hierarchical models, since our data occur at the country and the party levels. ${ }^{14}$ Our original dataset covers 75 ethnonational minority 


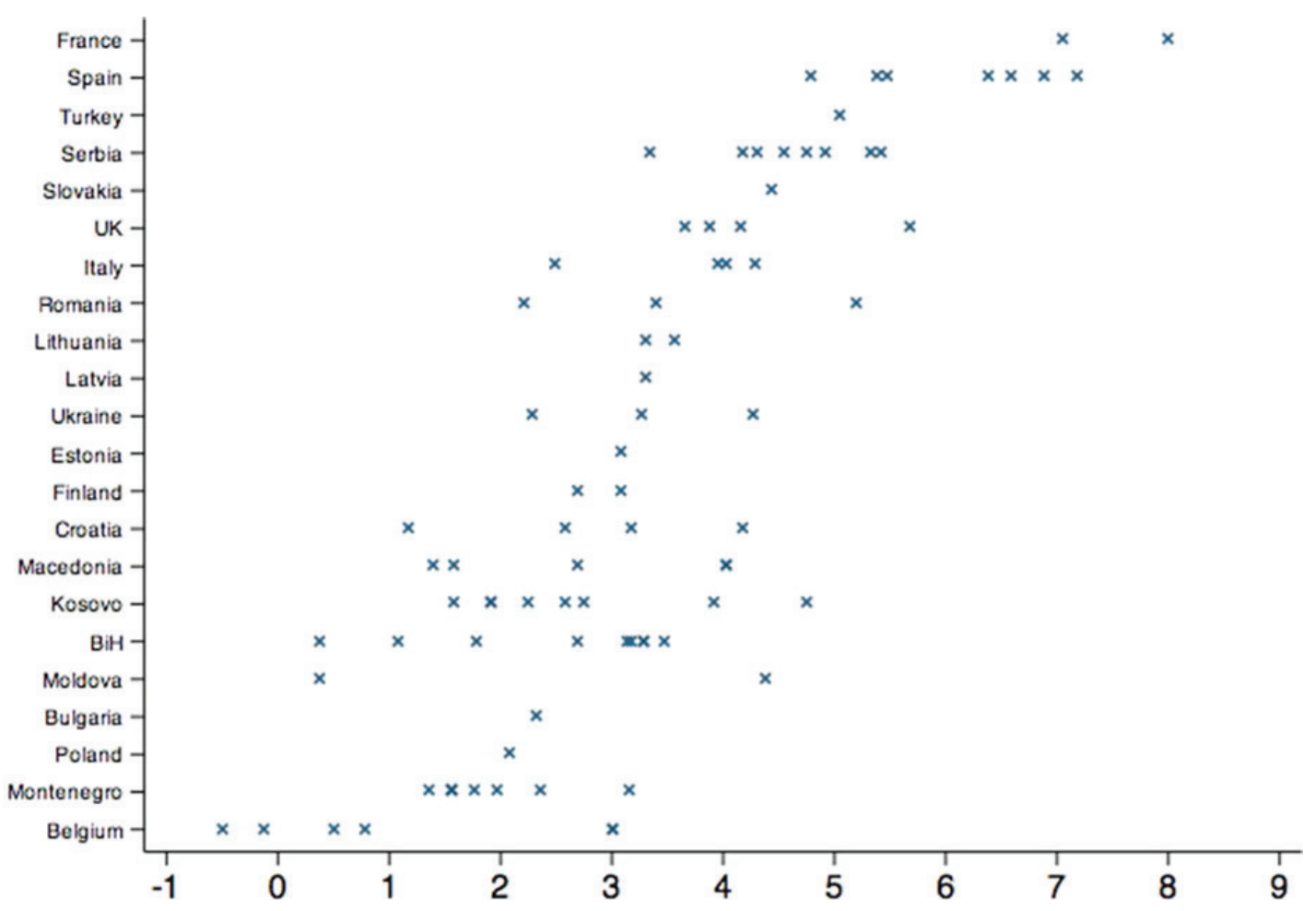

Figure 1. Ethnonational minority parties' relative position on ethnonational issues.

parties in the expert selection and 60 parties in the document selection. The regression analysis of relative extremism, however, comprises only 74 parties (expert selection) and 56 parties (document selection) due to missing data on demand-side segmentation in France, Poland and Sardinia (Italy) (see Appendix B).

\section{Results}

Figure 1 shows the distribution of ethnonational minority parties' positions relative to the party system mean on the ethnonational dimension by country. Negative values indicate that a minority party adopts a more moderate position on the ethnonational dimension than the party system mean, while positive values indicate a more extreme position. Countries are listed according to each country's mean ethnonational position for both samples of ethnonational minority parties. The Socialistische Partij Anders, representing the Flemish in Belgium, has the most moderate position on the ethnonational dimension relative to the party system mean. The most extreme position is that of Corsica Libera in France, with a score eight above the mean. ${ }^{15}$ The figure points to considerable variance in the relative extremism of ethnonational minority parties within and across European democracies.

Table 1 presents the results of OLS and two-level mixed effects restricted maximum likelihood (REML) regression analyses of ethnonational minority parties' extremism. ${ }^{16}$ Parties included in models 1 and 2 were selected based on expert knowledge, whereas parties included in models 3 and 4 were identified through document analysis. Models 1 and 3 are based on OLS regressions; models 2 and 4 are based on two-level regressions with parties nested in countries. 
Table 1. Results of ordinary least squares (OLS) and two-level linear regressions of ethnonational minority parties' extremism

\begin{tabular}{|c|c|c|c|c|}
\hline & \multicolumn{2}{|c|}{ Expert selection } & \multicolumn{2}{|c|}{ Document selection } \\
\hline & $\begin{array}{l}\text { OLS regression } \\
\text { Model } 1\end{array}$ & $\begin{array}{c}\text { Two-level } \\
\text { linear model } \\
\text { Model } 2\end{array}$ & $\begin{array}{l}\text { OLS regression } \\
\text { Model } 3\end{array}$ & $\begin{array}{c}\text { Two-level } \\
\text { linear model } \\
\text { Model } 4\end{array}$ \\
\hline $\begin{array}{l}\text { Demand-side } \\
\text { segmentation }\end{array}$ & $1.112(0.94)$ & $1.043(1.21)$ & $1.415(1.13)$ & $2.17^{*}(1.03)$ \\
\hline Supply-side segmentation & $-0.019^{* * * *}(0.00)$ & $-0.017^{*}(0.01)$ & $-0.008(0.01)$ & $-0.01(0.01)$ \\
\hline $\begin{array}{l}\text { Relative importance of } \\
\text { economic issues }\end{array}$ & $-0.451^{* * * *}(0.06)$ & $-0.421^{* * *}(0.05)$ & $-0.248^{* *}(0.09)$ & $-0.395^{* * *}(0.06)$ \\
\hline Disproportionality & $-2.208^{* * *}(0.29)$ & $-1.616^{* * *}(0.46)$ & $-1.191^{* * * *}(0.31)$ & $-0.912^{*}(0.45)$ \\
\hline Asymmetrical autonomy & $1.484^{* * *}(0.32)$ & $1.513^{* *}(0.46)$ & $1.713^{* * *}(0.36)$ & $1.502^{* * *}(0.39)$ \\
\hline $\begin{array}{l}\text { Minority-friendly } \\
\text { electoral rules }\end{array}$ & $-1.439^{* * *}(0.29)$ & $-1.034^{*}(0.41)$ & $-1.026^{* *}(0.33)$ & $-0.723(0.43)$ \\
\hline Constant & $6.175^{* * *}(0.54)$ & $4.983^{* * *}(0.89)$ & $4.732^{* * * *}(0.68)$ & $3.522^{* * * *}(0.88)$ \\
\hline Adjusted $\mathrm{R}^{2}$ & 0.669 & & 0.419 & \\
\hline $\mathrm{N}$ (parties) & 74 & & 56 & \\
\hline \multicolumn{5}{|l|}{ Variance components } \\
\hline Country-level $\left(\omega_{00}\right)$ & & 0.432 & & 0.934 \\
\hline Party-level $\left(\sigma^{2}\right)$ & & 0.6 & & 0.568 \\
\hline $\mathrm{N}$ (parties) & & 74 & & 56 \\
\hline $\mathrm{N}$ (countries) & & 19 & & 20 \\
\hline Log restricted-likelihood & & -99.962 & & -70.773 \\
\hline $\mathrm{ICC}$ & & 0.419 & & 0.622 \\
\hline
\end{tabular}

Notes: Dependent variable: relative extremism = expert judgment of a party's position on the ethnonational dimension subtracted from the party system's mean position on the ethnonational dimension. ${ }^{*} \mathrm{p}<0.05$; ${ }^{* *} \mathrm{p}<0.01 ;{ }^{* * *} \mathrm{p}<0.001$.

The segmentation of the electorate (demand-side segmentation) is always positively associated with extremism which is in line with H1a. However, the coefficient only reaches significance for the document selection of parties and when estimating a twolevel linear model. Given the hierarchical structure of our data, multilevel models are the more conservative estimation method (Steenbergen \& Jones 2002: 227). We can therefore conclude that those parties that openly appeal to a minority group in their official documents become more extreme, the more ethnically segmented the electorate.

All models show a negative impact of supply-side segmentation. The higher the seat shares of ethnonational minority and majority parties, the more moderate minority parties' position on the ethnonational dimension. This finding contradicts $H 1 b$. However, the effect is only significant when parties are selected according to expert knowledge. This could be explained by our measurement of supply-side segmentation based on the seat shares of ethnonational majority and minority parties. The measure also captures minorities' legislative representation. As parties gain more possibilities to articulate minority interests 
within the parliament, this might set incentives for moderating their positions as they need to cooperate with parties representing the majority group in order to influence policies.

The coefficient of the relative saliency of economic issues is statistically significant and negative for both party samples and is robust to the estimation method. This provides clear support for H2: as economic issues gain importance, parties become more moderate.

In addition, as the electoral system becomes more disproportional, ethnonational minority parties become less extreme. This result appears to confirm previous arguments that more disproportional electoral systems limit the number of intra-ethnic competitors and thereby incentives for outbidding. Second, parties that seek to represent groups within a minority region that enjoys asymmetrical territorial autonomy have significantly more extreme positions. This could imply that scholars such as Kymlicka (1998) are right to caution that territorial autonomy can provide a slippery slope to secession - an interpretation that would fall in line with a recent finding by Massetti and Schakel (2013b: 8), who analyse the effects of decentralisation reforms on the positions of regionalist parties on the basis of time-series data. However, the limits of cross-sectional analysis do not allow us to exclude potential endogeneity - meaning that the effect could also be a result of the fact that asymmetrical autonomy is used to appease those radical minority nationalists that voice credible threats to secession in the first place. Finally, in systems with more minority friendly electoral rules, ethnonational minority parties have less extreme positions. The OLS regression models explain 67 per cent of the variance for the expert-based selection and 42 per cent of the variance on extremism for the document-based selection.

To test the robustness of these findings, we first repeated the analysis without parties that were found to be distorted by expert bias in an earlier analysis of the validity and reliability of the EPAC data (Szöcsik \& Zuber 2015). Second, we excluded parties from Belgium, which was the only country where parties seeking to represent the majority group are aiming for secession and where we asked experts to treat the Flemish as the minority, despite opposite demographical realities. ${ }^{17}$ Third, we tested our hypotheses on an additional selection of parties based on expert answers to the question: 'Does the party seek to represent an ethnonational group in politics?' Contrary to the expert selection presented above, we now coded a party as ethnonational if a two-thirds majority of all country experts (including those that ticked 'no answer') answered the question in the affirmative. Our final models exclude parties from Kosovo, Turkey and South Tyrol, where no survey data was available to measure demand-side segmentation at an earlier point in time than party positions. All robustness checks support the finding that as economic issues become more important to parties relative to ethnonational issues, their positions on the ethnonational dimension become less extreme. Six of the seven estimated alternative models show that supply-side segmentation has a negative impact on ethnonational minority parties' nationalism. In line with $H 1 a$, demand-side segmentation is always positively associated with extremism, but never significant (see Appendix D).

\section{Conclusion}

The aim of this article was to explain the varying degrees of extremism of European ethnonational minority parties on an ethnonational dimension of competition that concerns the status of ethnonational groups and the nature of the state. In our theoretical framework, 
we combined arguments from the ethnic outbidding model with the more recent nested competition model to argue that the ethnic segmentation of the electoral market and the relative salience of the economic dimension influence parties' extremism. Whereas we expected high segmentation and one-dimensional ethnonational competition to provide incentives for extremism, low segmentation and nested competition on two dimensions (ethnonational and economic) should induce minority parties to play a more moderate role.

Since both the outbidding model and the nested competition model seek to explain why ethnic parties adopt more extreme positions than their competitors, we analysed parties' extremism relative to the mean ethnonational position within each party system. Our analysis first confirms the findings of recent studies that point to the variance of ethnic party strategies beyond radical outbidding. The considerable variance in the positions that European ethnonational minority parties adopt on an ethnonational dimension shows that parties appealing to territorially based ethnic groups have diverse, rather than unified extremist positions. The results of multivariate regression analyses show that this variance is associated with the varying stakes that parties have in different dimensions of the political issue space. Extremist positions are less likely the higher the stakes a party has in economic issues. This finding is robust whether we select ethnonational parties according to the explicit statements they make in their official documents or according to country expert knowledge, and stands up to a series of robustness checks. The ethnic segmentation of the electorate is always positively associated with extremism, but the effect is not significant across all models. Contrary to our expectations, the results of the majority of the estimated models show that higher supply-side segmentation is associated with more moderate relative positions on the ethnonational dimension. Since our measure of supply-side segmentation is based on the seat share of ethnic parties in national and regional parliaments, this finding could indicate the moderating effect of representation and policy influence of ethnonationalist minority parties' inclusion in the legislative arena. Controlling for the effect of institutions shows that whereas asymmetrical autonomy is positively associated with more extreme positions, a more disproportional electoral system and the existence of minority friendly electoral rules have a significant negative effect on extremism.

The empirical analysis presented in this article was restricted to a cross-sectional design because data on the positions of ethnonational parties on an ethnonational dimension of competition is so far only available for one point in time (i.e., 2011). It should, however, be noted that the patterns that hold for ethnonational minority parties in Europe are in line with the model of nested competition originally developed on the basis of case studies of ethnonational parties' strategic choices in Serbia that drew on causal process observations (Zuber 2012, 2013). The fact that we can robustly confirm one empirical implication of nested competition - that is, that parties that put more emphasis on alternative dimensions of competition adopt more moderate positions on the ethnonational dimension than their competitors - appears promising for causal inference when viewing the case studies and the quantitative analysis in a combined perspective. However, since the overall relationship between segmentation, salience and party positions is endogenous, future quantitative research should deal with the dynamics of party competition unfolding over time and analyse how ethnonational and other parties strategically respond to each other and to their voters on the basis of time-series data. ${ }^{18}$ 
In addition, the theory of nested competition (Zuber 2012) speaks of an alternative, ethnically cross-cutting dimension. The moderating effect of the importance of economic issues we found to obtain here can thus be expected to be conditional on whether the economic dimension cross-cuts the ethnonational dimension. If economic inequality is linked to ethnic identity, focusing on economic issues should not lead parties to adopt more moderate positions on ethnic issues since both their economic and their ethnic programme will appeal to the same, ethnically defined constituency. Future research could therefore investigate whether economic inequality between ethnic groups moderates the effect of the relative importance of the economic dimension. This could lead to a fruitful, closer connection between the literature on ethnic conflict focusing on structural variables like between-group inequality (Cederman et al. 2011) and the literature on ethnic party competition focusing on strategic interaction between group elites.

\section{Acknowledgments}

We thank David Klässig, Tomas Meizys and Dace Svilane for very valuable research assistance. Earlier drafts of this article were presented at: the conference on 'Ethnic Politics and Electoral Democracy', Zurich, June 2012; the MPSA annual meeting, Chicago, IL, April 2013; the 'Young Researchers' Workshop',ETH Zurich, April 2013; and the conference 'New Policies of Accommodating Diversity: Challenges and Opportunities for Multilevel States', University of Konstanz, June 2013. We thank participants from all of these occasions for their valuable feedback. Particular thanks go to two anonymous referees, Daniel Bochsler, Kanchan Chandra, Holger Döring, Liesbet Hooghe, Donald Horowitz, Phil Howe, André Kaiser, Emanuele Massetti, Ingo Rohlfing, Saskia Ruth, Arjan Schakel, Valentin Schröder and Hanna Schwander. All remaining errors are our own. We also thank all experts who participated in the EPAC expert survey for their willingness to share their knowledge with us. Following the rotation principle, both authors contributed equally to the EPAC data collection as well as the present article.

\section{Notes}

1. Following Chandra (2006: 398), 'ethnic identity' is defined as 'a subset of identity categories in which eligibility for membership is determined by attributes associated with, or believed to be associated with, descent'.

2. We use 'non-ethnic party' as a generic term for parties that appeal to voters irrespective of their ethnicity.

3. Ethno-regionalist parties thus combine an appeal to an ethnic constituency - the defining characteristic of ethnic parties (Chandra 2005:236) - with the programmatic demand for territorial self-government the defining characteristic of regionalist parties (Massetti \& Schakel 2013a:2). Due to the former feature, 
ethno-regionalist parties fall within the scope of predictions of theories of ethnic party competition. For analyses of the platforms of regionalist parties that are beyond the scope of theories of ethnic party competition and therefore this article, see Massetti and Schakel (2013a, 2013b), Sorens (2008) and Van Houten (2007).

4. An example of the former are Catalans in Spain; an example of the latter are Hungarians in Romania.

5. Though in the case of ethnic voting, this may be particularly difficult. Party systems with ethnic parties stabilise more quickly after democratisation since ethnic identity is a particularly powerful information cue, and ethnic belonging, though socially constructed, is more stable over time than other social identity categories (Birnir 2006; on the stable social orientation function of ethnic identity, see Hale 2008).

6. For lack of sovereignty, Bosnia and Herzegovina does not receive a Polity IV score. We included it since it is conducting free and fair elections under the supervision of the Organisation for Security and Cooperation in Europe (OSCE). We also included Kosovo, which is not unequivocally recognised as an independent state by the international community. The selected democracies are: Belgium, Bosnia and Herzegovina, Bulgaria, Croatia, Estonia, Finland, France, Italy, Kosovo, Latvia, Lithuania, Macedonia, Moldova, Montenegro, Poland, Romania, Serbia, Slovakia, Spain, Turkey, United Kingdom and Ukraine.

7. The supplementary documentation and replication data that will be provided online includes a coding protocol for the document-based classification.

8. The only multi-ethnic party we found was MOST-HID, appealing to Slovaks and Hungarians in Slovakia.

9. In addition, the introduction to the survey explicitly asked experts to evaluate parties' position relative to their competitors within the same party system.

10. The EPAC data covers also 'non-ethnic parties if they gained at least 5 per cent of the national voteshare in the most recent elections as of June 2010' (Szöcsik \& Zuber 2015). The dataset used to calculate the party system means covers 210 political parties.

11. We differentiate again between parties that appeal to groups with territorial autonomy and those without, assigning state-wide and regional values of supply-side segmentation, respectively.

12. We take seat shares because some smaller ethnic parties - particularly in the western Balkan countries contest elections as members of electoral alliances. Consequently, no data on their individual vote shares are available. Experts were able to identify the positions of these parties and assigned ethnonationalism scores to them that differed from the ethnonationalism scores assigned to their larger alliance partners.

13. Using an alternative measurement, the Regional Authority Index (Hooghe et al. 2010) leaves the effects of the main variables unchanged. The effect of RAI is insignificant and overall model fit worsens (results available from the authors upon request).

14. All models were estimated using Stata 12.

15. Shapiro and Wilk's (1965) W-test for normality and graphic exploration shows that the assumption of normal distribution of the dependent variable extremism is met. Data sources and summary statistics for all variables are provided in Appendices A, B and C.

16. Breusch-Pagan/Cook-Weisberg tests provided no evidence for heteroskedasticity.

17. The note read as follows: 'In all other countries included in this study, the groups potentially seeking hegemony by establishing a new nation-state are national minority groups. To maintain comparability with the coding of party positions in the other surveys, we kindly ask you to think of the Flemings and the Germans as national minority groups, and of the Walloons as the national majority group when answering question 1, despite the fact that this does not correspond to Belgian demographic realities.'

18. We plan to repeat the survey in 2016.

\section{References}

Agranoff, R. (1999). Intergovernmental relations and the management of asymmetry in federal Spain. In R. Agranoff (ed.), Accommodating diversity: Asymmetry in federal states. Baden-Baden: Nomos.

Alonso, S. (2005). Enduring ethnicity: The political survival of incumbent ethnic parties in new democracies. Available online at: www.wzb.eu/sites/default/files/personen/alonso.sonia.312/enduring-ethnicity.pdf

Alonso, S. (2012). Challenging the state: Devolution and the battle for partisan credibility - A comparison of Belgium, Italy, Spain and the United Kingdom. Oxford: Oxford University Press. 
Alonso, S., Gómez, B. \& Cabeza, L. (2013). Measuring centre-periphery preferences: The Regional Manifestos Project. Regional and Federal Studies 23(2): 189-211.

Anderson, B. (1991). Imagined communities: Reflections on the origin and spread of nationalism. London: Verso.

Benedikter, T. (2009). The world's modern autonomy systems: Concepts and experiences of regional territorial autonomy. Bozen: EURAC.

Bieber, F. (2008). Regulating minority parties in Central and South Eastern-Europe. In B. Reilly \& P. Nordlund (eds), Political parties in conflict-prone societies: Regulation, engineering and democratic development. Tokyo: United Nations University Press.

Birnir, J.K. (2006). Ethnicity and electoral politics. Cambridge: Cambridge University Press.

Bochsler, D. (2012). When two of the same are needed: A multi-level model of intra-ethnic group competition. Nationalism and Ethnic Politics 18(2): 216-241.

Cederman, L.E., Min, B. \& Wimmer, A. (2009). Ethnic power relations (EPR) [data file]. Available online at: http://hdl.handle.net/1902.1/11796UNF:5:k4xxXC2ASI204QZ4jqvUrQ==V1.

Cederman, L.E., Wimmer, A. \& Min, B. (2010). Why do ethnic groups rebel? New data and analysis. World Politics 62(1): 87-119.

Cederman, L.E., Weidmann, N.B. \& Gleditsch, K.S. (2011). Horizontal inequalities and ethnonationalist civil war: A global comparison. American Political Science Review 105(3): 478-495.

Chandra, K. (2005). Ethnic parties and democratic stability. Perspectives on Politics 3(2): 235-252.

Chandra, K. (2006). What is ethnic identity and does it matter? Annual Review of Political Science 9(1): $397-424$.

Chandra, K. (2011). What is an ethnic party? Party Politics 17(2): 151-169.

Coakley, J. (2008). Ethnic competition and the logic of party system transformation. European Journal of Political Research 47(6): 766-793.

Cohen, F.S. (1997). Proportional versus majoritarian ethnic conflict management in democracies. Comparative Political Studies 30(5): 607-630.

Deschouwer, K. (2003). Political parties in multi-layered systems. European Urban and Regional Studies 10(3): 213-226.

Elias, A. \& Tronconi, F. (eds) (2011). From protest to power: Autonomist parties and the challenges of representation. Vienna: Braumüller.

Gallagher, M. (1991). Proportionality, disproportionality and electoral systems. Electoral Studies 10(1): 3351.

Gallagher, M. \& Mitchell, P. (2008). The politics of electoral systems. Oxford: Oxford University Press.

Gellner, E. (1994). From kinship to ethnicity. In Encounters with nationalism. Cambridge, MA: Blackwell.

Hale, H.E. (2008). The foundations of ethnic politics: Separatism of states and nations in Eurasia and the world. Cambridge: Cambridge University Press.

Hooghe, L., Marks, G. \& Schakel, A.H. (2010). The rise of regional authority: A comparative study of 42 democracies. New York: Routledge.

Horowitz, D.L. (1985). Ethnic groups in conflict. Berkeley, CA: University of California Press.

Huber, J.D. (2012). Measuring ethnic voting: Do proportional electoral laws politicize ethnicity? American Journal of Political Science 56(4): 986-1001.

Kymlicka, W. (1998). Is federalism a viable alternative to secession? In P.Lehning (ed.), Theories of secession. London: Routledge.

Marks, G. et al. (2006). Party competition and European integration in the east and west: Different structure, same causality. Comparative Political Studies 39(2): 155-175.

Massetti, E. (2009). Explaining regionalist party positioning in a multi-dimensional ideological space: A framework for analysis. Regional and Federal Studies 19(4-5): 501-531.

Massetti, E. \& Schakel, A.H. (2013a). Between autonomy and secession: Decentralization and regionalist party ideological radicalism. Party Politics. doi: 10.1177/1354068813511380.

Massetti, E. \& Schakel, A.H. (2013b). Ideology matters: Why decentralisation has a differentiated effect on regionalist parties' fortunes in Western democracies. European Journal of Political Research 52(6): 797-821. 
McGarry, J. (2005). Asymmetrical federalism and the plurinational state. In F. Geerkens (ed.), Third International Conference on Federalism. Federalism: Turning diversity into harmony - Sharing best practices. Speeches, contributions and conclusions. Tielt: Lannoo.

Mill, J.S. (1861). Considerations on representative government, 2nd edn. London: Parker \& Bourn.

Mitchell, P., Evans, G. \& O'Leary, B. (2009). Extremist outbidding in ethnic party systems is not inevitable: Tribune parties in Northern Ireland. Political Studies 57(2):397-421.

Montabes Pereira, J., Ortega Villodres, C. \& Pérez Nieto, E.G. (2006). Sistemas electorales y apoyo electoral de los partidos regionalistas en Europa Occidental. Revista Espanola de Ciencia Política 15: 93-122.

Newman, S. (1997). Ideological trends among ethnoregional parties in post-industrial democracies. Nationalism and Ethnic Politics 3(1): 28-60.

ProDG.be (n.d.). Grundsatzprogramm. Available online at: http://prodg.be/wp-content/uploads/2013/03/ Grundsatzprogramm.pdf

Rabushka, A. \& Shepsle, K.A. (1971). Political entrepreneurship and patterns of democratic instability in plural societies. Race and Class 12(4): 461-476.

Rabushka, A.\& Shepsle, K.A. (1972). Politics in plural societies: A theory of democratic instability. Columbus, $\mathrm{OH}$ : Charles E. Merrill.

Reynolds, A. (2006). Electoral systems and the protection and participation of minorities: Report of Minority Rights Group International. Available online at: www.minorityrights.org/download.php@id=161

Shapiro, S.S. \& Wilk, M.B. (1965). An analysis of variance test for normality (complete samples). Biometrika 52(3-4): 591-611.

Sorens, J. (2008). Regionalists against secession: The political economy of territory in advanced democracies. Nationalism and Ethnic Politics 14(3): 325-360.

Steenbergen, M.R. \& Jones, B.S. (2002). Modeling multilevel data structures. American Journal of Political Science 46(1): 218-237.

Stepan, A. (2001). Arguing comparative politics. Oxford: Oxford University Press.

Szöcsik, E. \& Bochsler, D. (2013). All jointly or everyone on its own? On fissions and fusions of ethnic minority parties. In J. Danero, N. Stojanovic \& S. Weinblum (eds), New nation-states and national minorities. Colchester: ECPR Press.

Szöcsik, E. \& Zuber, C.I. (2015). EPAC: A new dataset on ethnonationalism in party competition in 22 European democracies. Party Politics 21(1): 153-160.

Tronconi, F. (2006). Ethnic identity and party competition: An analysis of the electoral performance of ethnoregionalist parties in Western Europe. World Political Science Review 2(2): 137-163.

Tsebelis, G. (1990). Nested games: Rational choice in comparative politics. Berkeley, CA: University of California Press.

Van Houten, P. (2007). Regionalist challenges to European states: A quantitative assessment. Ethnopolitics 6(4): 545-568.

Wagner, M. (2012). Defining and measuring niche parties. Party Politics 18(6): 845-864.

Zuber, C.I. (2012). Ethnic party competition beyond the segmented market. Nationalities Papers 40(6): 927944.

Zuber, C.I. (2013). Beyond outbidding? Ethnic party strategies in Serbia. Party Politics 19(5): 758-777.

Address for correspondence: Christina Zuber, Department of Politics and Public Administration, University of Konstanz, Universitatsstraße 10,78457 Konstanz, Germany. E-mail: mail@christinazuber.com 